\title{
COURT SHOE PRODUCTION LINE: IMPROVEMENT OF PROCESS CYCLE EFFICIENCY BY USING LEAN TOOLS
}

\author{
Md. Abu SAYID MIA ${ }^{1,2^{*}}$, Md. NUR-E-ALAM ${ }^{3}$, M. Kamal UDDIN ${ }^{2}$ \\ ${ }^{1}$ Institute of Leather Engineering and Technology, University of Dhaka, Dhaka-1209, Bangladesh \\ ${ }^{2}$ Institute of Appropriate Technology, Bangladesh University of Engineering and Technology, Dhaka-1000 \\ ${ }^{3}$ Leather Research Institute (LRI), Bangladesh Council of Scientific and Industrial Research, Savar, Dhaka-1350, Bangladesh
}

COURT SHOE PRODUCTION LINE: IMPROVE PROCESS CYCLE EFFICIENCY BY USING LEAN TOOLS

ABSTRACT. Lean manufacturing is an applied methodology of scientific, objective techniques that cause work tasks in a process to be performed with a minimum of non-value adding activities resulting in greatly reduced wait time, queue time, move time, administrative time, and other delays. This work addresses the implementation of lean principles in a footwear manufacturing industry in order to evaluate present Process Cycle Efficiency (PCE) and lead time prior to developing an improved strategy to bring the improved PCE and to reduce the lead time. At the present state, the PCE was found $8.32 \%$ and after the implementation of lean tools, it would be $19.46 \%$ at the future state where lead time would also be reduced by $57.24 \%$ evaluated by Pareto analysis and value stream mapping (VSM) tools. The production flow was optimized by minimizing several non-value added activities and time such as bottlenecking, machine breakdown, queue time, waiting time, material handling time, etc. Eventually, this study will be useful in developing a more generic approach to design lean environment in the management system of the studied " $X$ " Footwear Industry in Bangladesh.

KEY WORDS: lean tools, VSM, lead time, PCE, technology assessment, court shoe, Bangladesh

LINIE DE PRODUCTIE A PANTOFILOR CLASICI: ÎMBUNĂTĂTIREA EFICIENTEI PROCESULUI PRIN UTILIZAREA INSTRUMENTELOR SUPLE REZUMAT. Producția suplă este o metodologie aplicată pe baza unor tehnici științifice și obiective care presupune ca sarcinile de lucru din cadrul unui proces să fie realizate cu un minim de activități fără valoare adăugată, ceea ce are ca rezultat reducerea timpului de așteptare, timpului de mișcare, timpului de administrare și altor întârzieri. Această lucrare abordează implementarea unor principii suple într-o fabrică de încălțăminte pentru a evalua eficiența ciclului de proces (PCE) existent și timpul de execuție înainte de a dezvolta o strategie pentru a îmbunătăți PCE și pentru a reduce timpul de execuție. În starea actuală PCE a fost estimat la 8,32\%, iar după punerea în aplicare a instrumentelor suple, ar crește în viitor la 19,46\%, iar timpul de execuție ar fi redus cu 57,24\%, evaluat prin analiza Pareto și instrumentele de cartografiere a fluxului de valori (VSM). Fluxul de producție a fost optimizat prin reducerea la minimum a mai multor activități și timpi fără valoare adăugată, cum ar fi blocajele, defectarea mașinilor, timpul de așteptare, timpul de manipulare a materialelor etc. În cele din urmă, acest studiu va fi util în dezvoltarea unei abordări mai generice pentru proiectarea unei producții suple în sistemul de management al fabricii de încălțăminte „X" din Bangladesh.

CUVINTE CHEIE: instrumente suple, VSM, timp de execuție, PCE, evaluarea tehnologiei, pantofi clasici, Bangladesh

LIGNE DE PRODUCTION DES CHAUSSURES CLASSIQUES: AMÉLIORER L’EFFICACITÉ DU PROCÉDÉ EN UTILISANT LES OUTILS DE GESTION ALLÉGÉE

RÉSUMÉ. La production allégée est une méthodologie appliquée à partir des techniques scientifiques et objectives qui impliquent que les tâches de travail dans un processus soient réalisées avec un minimum d'activités à valeur ajoutée, entraînant la réduction des temps d'attente, des temps d'administration et d'autres retards. Cet article traite de la mise en œuvre de principes de gestion allégée dans une entreprise de fabrication de chaussures pour évaluer l'efficacité du cycle de processus existant (PCE) et du temps d'exécution avant d'élaborer une stratégie pour améliorer le PCE et réduire le temps d'exécution. Dans l'état actuel, le PCE a été estimé à 8,32\% et, après la mise en œuvre des outils de gestion allégée, il augmenterait à 19,46\% à l'avenir et le temps d'exécution serait réduit de 57,24\%, évalué par l'analyse de Pareto et les outils de cartographie du flux de valeur (VSM). Le flux de production a été optimisé en minimisant les multiples activités et les temps sans valeur ajoutée tels que les goulots d'étranglement, les pannes de machines, les temps d'attente, les temps de traitement des matériaux, etc. Enfin, cette étude sera utile pour développer une approche plus générique pour concevoir une production allégée dans le système de gestion de l'entreprise de fabrication de chaussures " $\mathrm{X}$ " du Bangladesh.

MOTS CLÉS: outils de gestion allégée, VSM, temps d'exécution, PCE, évaluation de la technologie, chaussures classiques, Bangladesh

\section{INTRODUCTION}

Lean manufacturing is based on the Toyota Production System developed by Toyota which focuses on eliminating waste, reducing inventory, improving throughput, and encouraging employees to bring attention to problems and suggest improvements to fix them [1]. Lean manufacturing has increasingly been applied by leading manufacturing companies throughout the world. Today Higher Productivity achievement is the very important factor for the production field [2]. A core concept of lean manufacturing is pulling production in

\footnotetext{
* Correspondence to: Md. Abu Sayid MIA, Institute of Leather Engineering and Technology, University of Dhaka, Dhaka-1209, Bangladesh,
} E-mail: emsayid@gmail.com, Contact: +8801674772545 
which the flow on the factory floor is driven by demand from downstream pulling production upstream. Some of the changes required by lean manufacturing can be disruptive if not implemented correctly and some aspects of it are not appropriate for all companies [3]. A lean manufacturing facility is capable of producing the product in only the sum of its value added work content time. On the other hand, applications of lean manufacturing in the continuous process sector have been far fewer [4]. It has sometimes been argued that in part, this is because such industries are inherently more efficient and have a relatively less urgent need for major improvement activities. Managers have also been hesitant to adopt lean manufacturing tools and techniques to the continuous sector because of other characteristics that are typical in this sector. These include large, inflexible machines, long setup times, and the general difficulty in producing in small batches. While some lean manufacturing tools might indeed be difficult to adapt to the continuous sector, this does not mean that the approach is completely inapplicable; for example, [5-11] examine aspects of continuous production that are amenable to lean techniques and present a classification scheme to guide lean implementation in this sector. Features of a typical lean manufacturing model include one unit at a time production; non-value added time eliminated production in the work content time only, and relocation of required resources to the point of usage. In the present day of manufacturing, the assembly line can be formed easily for any industry whether it is a small-scale or a large-scale industry. When the takt times are calculated for every part manufactured in the industry through different part movements, then the problem of locating machines on the shop floor occurs when it is a job type production unit; this problem is the main reason for reconfiguration of machines and layout design for every demand [12]. To eliminate these problems, a proper method is required to achieve a rhythm in manufacturing lean assembly line by identifying value adding, non-value adding, and necessary non-value adding activities through an optimum feasible takt time [13]. This study had the specific objectives to identify, quantify and to reduce the non-value added (NVD) activities and time towards the exalted Process Cycle Efficiency (PCE) and therefore to reduce the lead time.

\section{INDUSTRIAL IMPLEMENTATIONS OF LEAN TOOLS}

With the flow of time and iridescent aptitude of the consumer, today's manufacturing industries are undergoing more and more competition in local and global marketing system to come up with the desired product or service within a limited period of time. Towards reducing the lead time, improving the PCE and ultimately to gain the benefit there is compelling evidence of successful lean tools implementation in the manufacturing world. Lean tools have been successfully applied in many manufacturing organizations such as General Electric, Boeing, DuPont, Kodak, Honeywell, Texas Instruments, etc [14]. Lean tools are also successfully applied in hospitals, pharmaceutical, housing and paper industry, and brought with alluring economic benefit by reducing the long lead time and manufacturing waste. It was estimated that over the world by adopting lean tools in pharmaceutical industry a cost could be saved up to $\$ 90$ billion per year [15]. In 1999, it was evaluated that lean tools significantly brought the benefits of $\$ 20$ billion to Motorola Inc. since 1986 that inspired many companies in various industrial sectors to adopt lean tools. In the USA, it was reported that a food manufacturing industry has gained the benefit of $\$ 2$ million per year by adopting lean tools [16]. This riveting economic benefit was the ultimate outcome of reduced NVD activities, lead time and improved PCE. It was shown a frozen fish industry would able to improve its PCE from $5.02 \%$ to $17.46 \%$ by adopting lean tools [17]. Like these promising studies, the authors were provoked to conduct this study with the lean tools in a court shoe production line of a footwear manufacturing company in Bangladesh prior to reducing the lead time and to improve the PCE. The demand of processed footwear is rapidly increasing in the busy world and consequently, it seems there is a rapid expansion of footwear industry in Bangladesh similarly to other countries [18]. 


\section{OBSERVED PRODUCTION LINE}

In this study, the required materials towards the finished court shoe were not the concerning matter rather than causes that were responsible for production waste and down time. The delay in production due to different causes and downtime were quantified in terms of NVD time. The basic stages of court shoe production line are shown in the following Figure 1.

\section{Value Stream Mapping (VSM)}

A value stream is a collection of all actions (value added as well as non-value-added) that are required to bring a product (or a group of products that use the same resources) through the main flows, starting with raw material and ending with the customer. These actions consider the flow of both information and materials within the overall supply chain. The ultimate goal of VSM is to identify all types of waste in the value stream and to take steps to try and eliminate these [19]. While researchers have developed a number of tools to optimize individual operations within a supply chain, most of these tools fall short in linking and visualizing the nature of the material and information flow throughout the company's entire supply chain. Taking the value stream viewpoint means working on the big picture and not individual processes. VSM creates a common basis for the production process, thus facilitating more thoughtful decisions to improve the value stream [20].

\section{Present Value Steam Mapping (VSM) of Court Shoe Production Line}

To draw the present VSM relevant data in the following Figure 2 as VD and NVD time, Cycle time $(C / T)$, Change Over time, Uptime $(U / T)$,

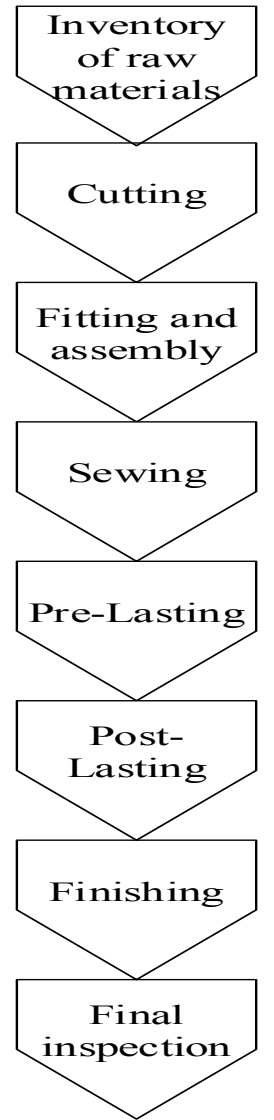

Figure 1. Basic stages of Court shoe production line

Lot size, quantity to deliver, delivery time were observed and information related to assembly line such as production time, inventory storages, inspections, rework loops, number of workers and operational hours per day were collected and documented in Table 1 and Table 2. To draw the completion of present VSM of Court shoe production line, a timeline was added at the bottom of the map recording the VD and NVD time.

Table 1: Manufacturing lead time of Court Shoe Production Line

\begin{tabular}{cccccccccc}
\hline Times & \multicolumn{3}{c}{ Sewing } & \multicolumn{4}{c}{ Lasting } & \multicolumn{3}{c}{ Finishing } \\
& $\mathrm{D} / \mathrm{T}(\mathrm{Sec})$ & $\mathrm{C} / \mathrm{T}(\mathrm{Sec})$ & $\mathrm{U} / \mathrm{T}(\%)$ & $\mathrm{D} / \mathrm{T}(\mathrm{Sec})$ & $\mathrm{C} / \mathrm{T}(\mathrm{Sec})$ & $\mathrm{U} / \mathrm{T}(\%)$ & $\mathrm{D} / \mathrm{T}(\mathrm{Sec})$ & $\mathrm{C} / \mathrm{T}(\mathrm{Sec})$ & $\mathrm{U} / \mathrm{T}(\%)$ \\
\hline $1^{\text {st }}$ & 474 & 2760 & 83 & 862 & 2400 & 64 & 384 & 1620 & 76 \\
$2^{\text {nd }}$ & 487 & 2760 & 82 & 869 & 2400 & 64 & 385 & 1620 & 76 \\
$3^{\text {rd }}$ & 474 & 2760 & 83 & 849 & 2400 & 65 & 388 & 1620 & 76 \\
\hline
\end{tabular}

Note: Sewing m/c speed: 350 RPM; Lasting m/c speed: 400 RPM; finishing m/c speed: 15 cases per min. Batch production-4000 pairs. 
Table 2: Present lead time of Court Shoe Production Line

\begin{tabular}{ccc}
\hline Production stages & VD time (Sec) & NVD time (Sec) \\
\hline Receiving inventory & 00 & 28800 \\
Cutting & 600 & 1200 \\
Fitting \& Assembly & 1200 & 240 \\
Sewing & 2297 & 703 \\
Pre-lasting & 00 & 672 \\
Post-lasting & 1650 & 1372 \\
Finishing & 1231 & 702 \\
Shipping inventory & 00 & 43200 \\
Total & $6978(8.32 \%)$ & $76889(91.68 \%)$ \\
\hline
\end{tabular}

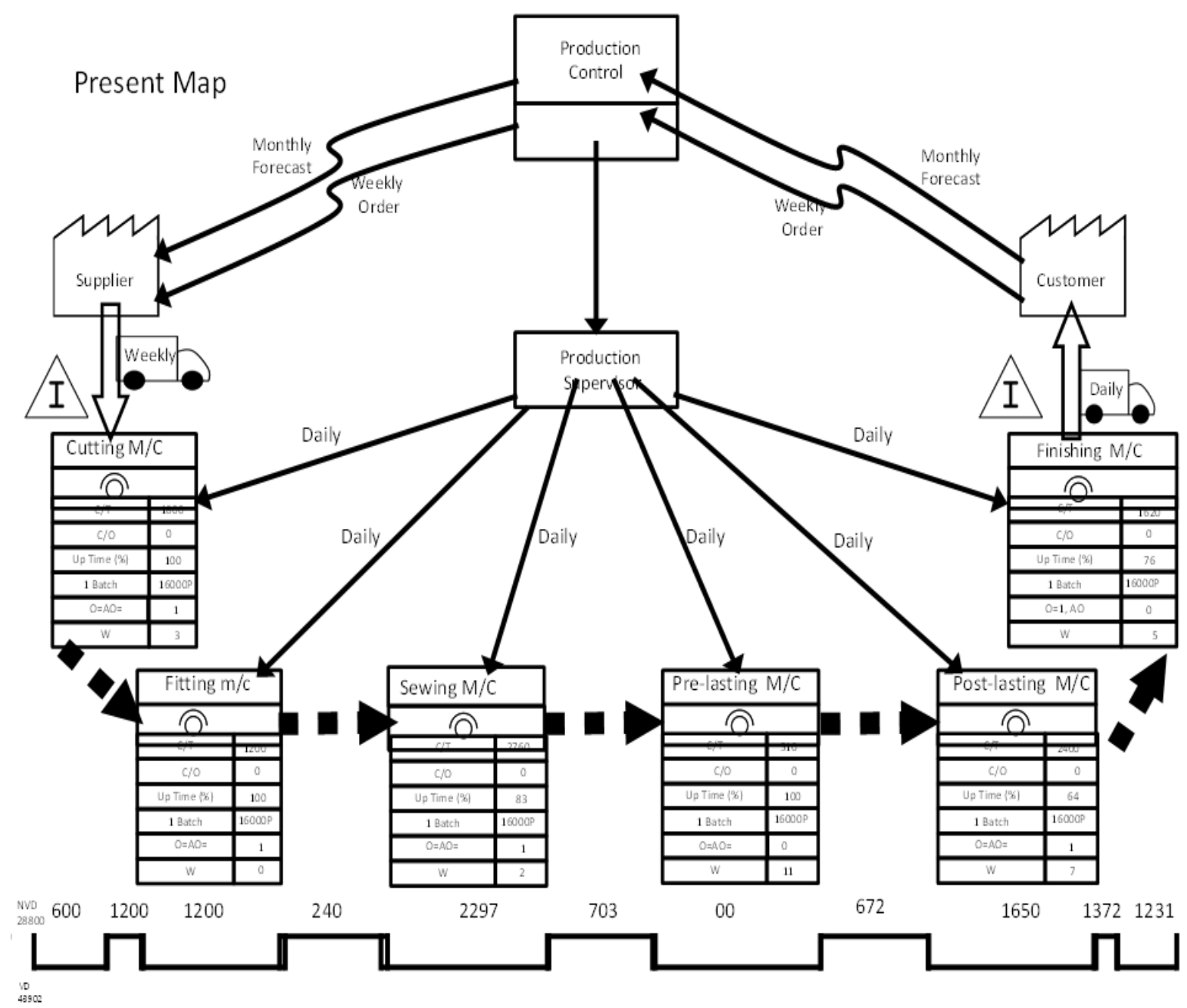

Figure 2. Present Value Steam Mapping (VSM) of Court Shoe Production Line 
It helps to draw the required production steps with mentioning required labor, $\mathrm{C} / \mathrm{T}, \mathrm{U} / \mathrm{T}$, $\mathrm{C} / \mathrm{O}$ and batch size. By observing the present scenario regarding production line, the following questions can be answered: how much labor is needed at different production units? How much is VD \& NVD time present? Where \& what kind of improvement should be done? It helps to calculate the PCE, lead time and takt time.

\section{Present PCE of Court Shoe Production Line}

PCE is measured as the percentage of the ration of VD time and lead time, where lead time is the summation of VD and NVD time. In the observed production line, the VD and NVD time were found as $6978 \mathrm{sec}$ and $76889 \mathrm{sec}$, so the lead time was $83867 \mathrm{sec}$ and consequently, the PCE was $8.32 \%$ which could be considered below the internationally comparative level $25 \%$ [17]. Throughout this study, it was strived to improve the present PCE with the proper adoption of lean tools such as VSM, Pareto analysis, Pareto chart, 5S, and JIT.

\section{Present Takt Time of Court Shoe Production Line}

Takt time is considered as the time that is required to produce a single unit of daily capable quantity of commodities [21]. The studied production line runs for two shifts per day, each shift was for $33600 \mathrm{sec}$ excluding lunch time and planned down time; therefore, the available time for the run of the studied production line was $67200 \mathrm{sec}$ with the daily customer demand of 9333 cases where each case contains 250 pairs court shoe and every shoe size is UK 9. Takt time is considered as the heartbeat of any process line. By this way, the present takt time of studied production line was $7.20 \mathrm{sec}$ i.e. it took $7.20 \mathrm{sec}$ to produce a single case of court shoe production. By this study, it was tried to reduce the present takt time with the proper implementation of lean tools.

\section{Pareto Analysis}

It is a statistical technique in decision making that is used for selection of a limited number of tasks that produce significant overall effect. It uses the Pareto principle - the idea that by doing $20 \%$ of work, $80 \%$ of the advantage of doing the entire job can be generated. Or in terms of quality improvement, a large majority of problems $(80 \%)$ are produced by a few key causes (20\%) [22]. The Pareto Principle is also known as the "80/20 Rule" which is the idea that $20 \%$ of causes generate $80 \%$ of results [2325]. In this study, by using this tool it was tried to find out the $20 \%$ of causes that is generating $80 \%$ NVD activities. This tool focuses on the most damaging causes on a project. In this essence, David stated that the application of the Pareto chart consisting of causes for downtime or NVD activities along the $X$ axis while the $Y$ axis represents the cumulative percentage of downtime. Most of the NVD activities were documented on sewing, pre-lasting, post-lasting and finishing steps where these were frequently observed due to different causes. The highest frequency of NVD activities that derived the down time was found for toe lasting problems while skipped stitches were the lowest frequency.

Table 3: Causes of delay times for Pareto analysis of Court Shoe Production Line

\begin{tabular}{cccc}
\hline Causes of delay times & Down Time (D/T) & Percentage of D/T & Cumulative of percentage \\
\hline Toe lasting problems & 526 & 30.4750869 & 30.4750869 \\
Needle thread breakage & 303 & 17.5550406 & 48.03012746 \\
Inefficient ironing & 171 & 9.90730012 & 57.93742758 \\
Seat lasting problems & 103 & 5.96755504 & 63.90498262 \\
Inappropriate scouring & 97 & 5.61993048 & 69.52491309 \\
Inappropriate chilling & 91 & 5.27230591 & 74.797219
\end{tabular}




\begin{tabular}{cccc} 
Improper polishing & 91 & 5.27230591 & 80.06952491 \\
Seam pucker & 89 & 5.15643105 & 85.22595597 \\
Bobbin thread breakage & 53 & 3.07068366 & 88.29663963 \\
Side lasting problems & 43 & 2.49130939 & 90.78794902 \\
Inefficient spraying & 42 & 2.43337196 & 93.22132097 \\
Long mark defects & 41 & 2.37543453 & 95.5967555 \\
Bumps or hollows & 41 & 2.37543453 & 97.97219003 \\
Skipped stitches & 35 & 2.02780997 & 100 \\
\hline
\end{tabular}

Different causes of NVD activities or down time at different production stages were documented in Table 3 with their frequency in terms of percentage and cumulative of percentage. Pareto chart is constructed in Figure
3 where the responsible causes for NVD activities were arranged in downward movements in terms of their frequency. $5 \mathrm{~S}$ and JIT would be effective initiatives to remove these most frequent causes.

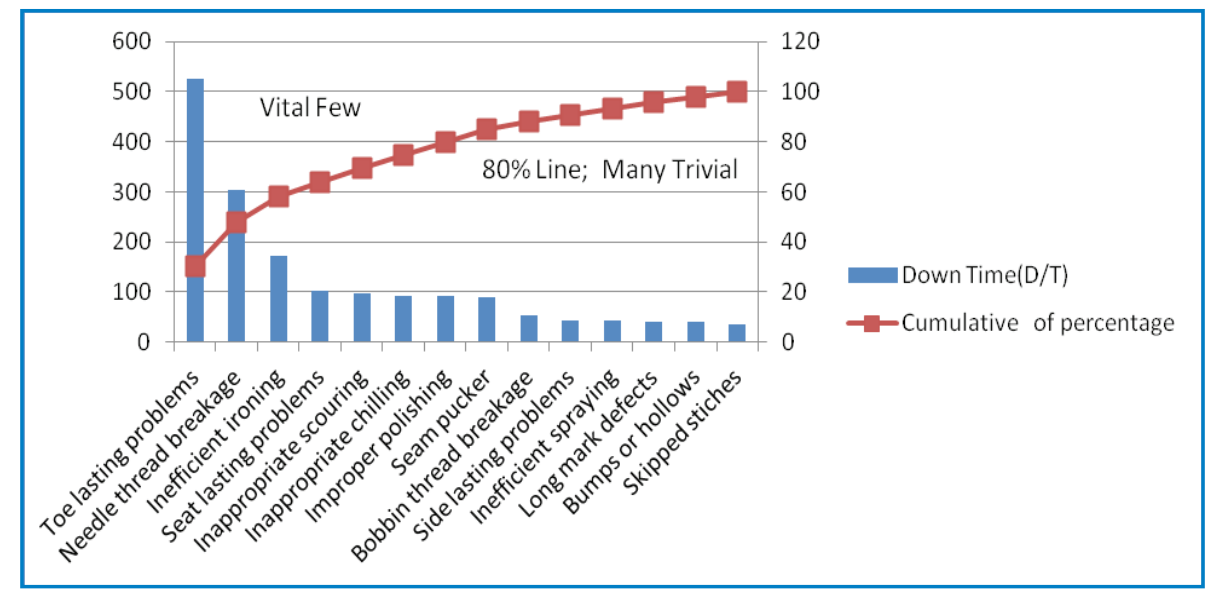

Figure 3. Pareto chart of Court Shoe Production Line

\section{IMPROVEMENT STRATEGIES}

In order to remove the $80 \%$ NVD activities, some improvement strategies are required such as increasing skilled manpower, continuous improvement, and involvement of JIT philosophy within the production management system.

\section{Increase Skill Manpower}

It was observed that most of the assistant operators were not skilled enough to handle the machine breakdown immediately. But for this reason, the maintenance time was as high as not acceptable. So, it is suggested to hire some skilled manpower as operator and assistant operator especially for sewing, lasting and finishing machine. The effective training program should be arranged prior to make capable of operator and assistant operator towards reducing the maintenance time.

\section{Continuous Improvement}

Continuous improvement is one of the most effective and basic tools of lean production which is also known as Kaizen. It is a longterm approach to work systematically to seek and to achieve small, incremental changes in processes in order to improve the efficiency and quality. Kaizen can be applied to any kind of work, but it is well known for being used in lean manufacturing. Kaizen is a Japanese term that reveals the meaning as "good change". Basically Kaizen is considered as a systematic approach for continuous improvement. $5 \mathrm{~S}$ is one of the most popular tools for effective continuous improvement. Towards the NVD activities reduction, $5 S$ is the first modular step. $5 S$ is 
not only a means to increase the profitability of a firm but also allow companies to reveal potential strengths and capabilities that were hidden before [26]. It consists of Japanese words - Seiri (Sort), Seiton (Straighten), Seiso (Sweep and Clean), Seiketsu (Systemize), and Shitsuke (Standardize). The basic and underlying concept of $5 \mathrm{~S}$ is looking for waste and then trying to eliminate it. This concept implies instantly going where there is a problem, checking out the problem, taking a temporary measure on the spot, finding out the main causes beyond the problem, if necessary using the five WHY? Questions; and finally standardizing to prevent reoccurrence [27]. In a production process line, a good change or the improvement can be achieved in many ways such as reduction of inventory, reduction of production time, reduction of defective parts etc. In this essence, a strategic plan is developed prior to implementing the $5 \mathrm{~S}$ in the observed Court Shoe production line in order to remove the recognized NVD activities. Towards the implementation of 5S, a proper plan or vision is required which could be formulated by the management of footwear sector. The vision plan should be incorporated with the theme of reducing lead time, NVD activities or manufacturing waste and improving PCE. The implemented $5 \mathrm{~S}$ plan consists of team work, training work, multi skill scope and learning environment. To implement a new plan, a team work will be an effective wheel to bring the plan into practice. An effective training program should be arranged frequently prior to need for the sake of $5 \mathrm{~S}$ incorporation within the existing production management system. There should be a constant attempt to find out the problem at each and every stage of the Court Shoe production line. A persistent endeavor should be kept on creating a way to eliminate the arising

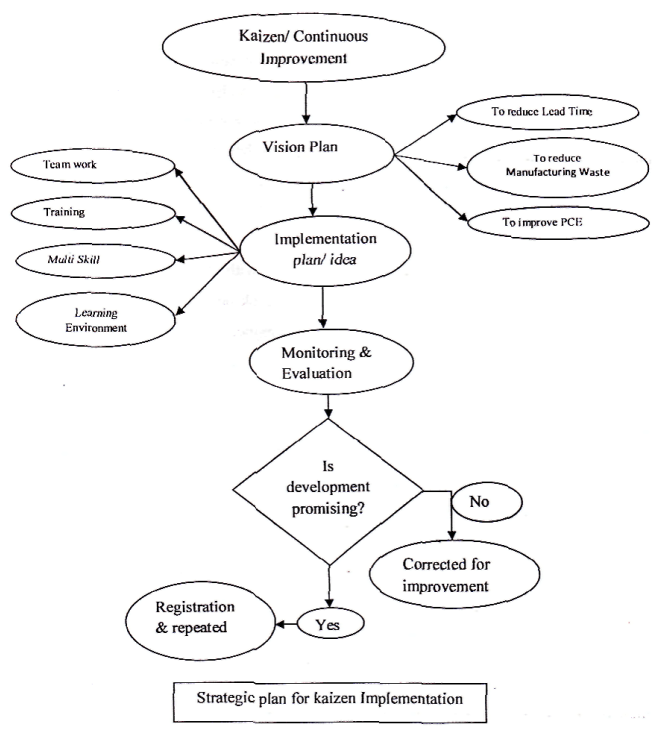

Figure 4. Strategic plan for kaizen implementation

problems and if this way is effective, it must be documented, and if not, attempts should continue towards an effective way beyond the elimination of problems for NVD activities.

\section{Just in Time (JIT)}

JIT is a Japanese management philosophy which has been applied in many Japanese manufacturing organizations since the early 1970s. It was first developed by Taiichi Ohno in the Toyota manufacturing plants as a means of meeting consumer demands within the minimum delays. The lean production firstly focuses on what is most commonly thought of as 'just in time' management which is considered as one of the basic principles of lean manufacturing. It is the idea of producing exactly what the customer wants, in the quantities they want, where they want it, when the customer wants it without being delayed or held upon inventory [28]. Inman and Bulfin [29] implied that JIT implementation provokes to reduce hurdles like long change over time; unleveled production schedules; highly variable production processes; large container sizes; severe bottlenecks and long lead time. 
A system where a customer initiates demand and the demand is then transmitted back from the final assembly all the way to raw material, thus "pulling" all requirements just when they are required [30, 31]. Actually, there are no unified steps towards the IIT implementation; because, the production phenomenon of different factories varies from each other. Moreover, the ability of the different techniques in different factories depends deeply on a specific manufacturing environment. However, benefits from these programs have often been limited because of unreliability or inflexibility [32]. Indeed, it is needed a reliable and flexible environment towards the JIT implementation. In the observed court shoe production line unwanted and unnecessary NVD waiting times were observed as very common between each two stages, especially in raw material inventory and finished goods inventory which could be reduced by JIT implementation. In order to implement JIT, some suggestions were proposed such as:

- Prepare the plant and its personnel for flexibility towards involving themselves within the JIT principles;

- $\quad$ Regarding personnel should be careful to the shortest lead time and high quality by concentrating maintenance and quality;

- $\quad$ Strive to produce with no waste by focusing on inventory control.

\section{THE FUTURE STATES OF COURT SHOE PRODUCTION LINE}

\section{Future VSM of Court Shoe Production Line}

Finally, the future VSM is constructed as shown in Figure 4 which reported a promising reduction in NVD time and lead time with improved PCE and up time. Table 5 outlines the value stream analysis report for the future state. It is found that after the implementation of lean tools PCE will be improved at internationally competitive level. Based on intense observation, brainstorming and previous regarding studies it is predicted that $50 \%$ NVD time of raw material inventory and shoe production steps could be reduced. The $80 \%$ NVD time of Sewing, pre-lasting, pot-lasting and finishing steps could be reduced after the implementation of lean tools. At future state, the total labor cost is found 17 , but it was 25 at present state i.e. after the implementation lean tools. At future state, the total labor is found 20 , but it was 36 at present state i.e. after the implementation of lean tools at least 15 labors could be the relief for another work. Then up time of sewing, lasting and finishing machine is found consecutively $96 \%$, $93 \%$, and $95 \%$ while it was consecutively $83 \%$, $64 \%$, and $76 \%$ at present state. At future state, it is also found the PCE will be $19.46 \%$ while it was $8.32 \%$ at present state. Therefore, at future state, the promising outcomes bring with the reduction of labor, NVD time and lead time, and improved up time and PCE.

Table 4: Future lead time analysis of Court Shoe Production Line

\begin{tabular}{ccc}
\hline Production stage & Value Added Time (Sec) & Non-Value Added Time (Sec) \\
\hline Receiving Inventory & 00 & $14400(50 \%)$ \\
Cutting & 600 & $600(50 \%)$ \\
Fitting \& Assembly & 1200 & $240(0 \%)$ \\
Sewing & 2297 & $140(80 \%)$ \\
Pre-lasting & 00 & $134(80 \%)$ \\
Post-lasting & 1650 & $274(80 \%)$ \\
Finishing & 1231 & $140(80 \%)$ \\
Shipping Inventory & 00 & $12960(70 \%)$ \\
Total & $6978(19.46 \%)$ & $28888(80.54 \%)$ \\
\hline
\end{tabular}

\section{Expected PCE at Future State}

At future state, it is expected that after the proper implementation of lean tools NVD time from $76889 \mathrm{sec}$ to $28888 \mathrm{sec}$, and thus the lead time would be reduced from $83867 \mathrm{sec}$ to 35866 sec. As earlier it is mentioned that PCE is measured as the percentage of the ratio of VD time and lead time and consequently at future state, the PCE is found $19.46 \%$ which is considered as the internationally competitive level $25 \%$ [17]. 


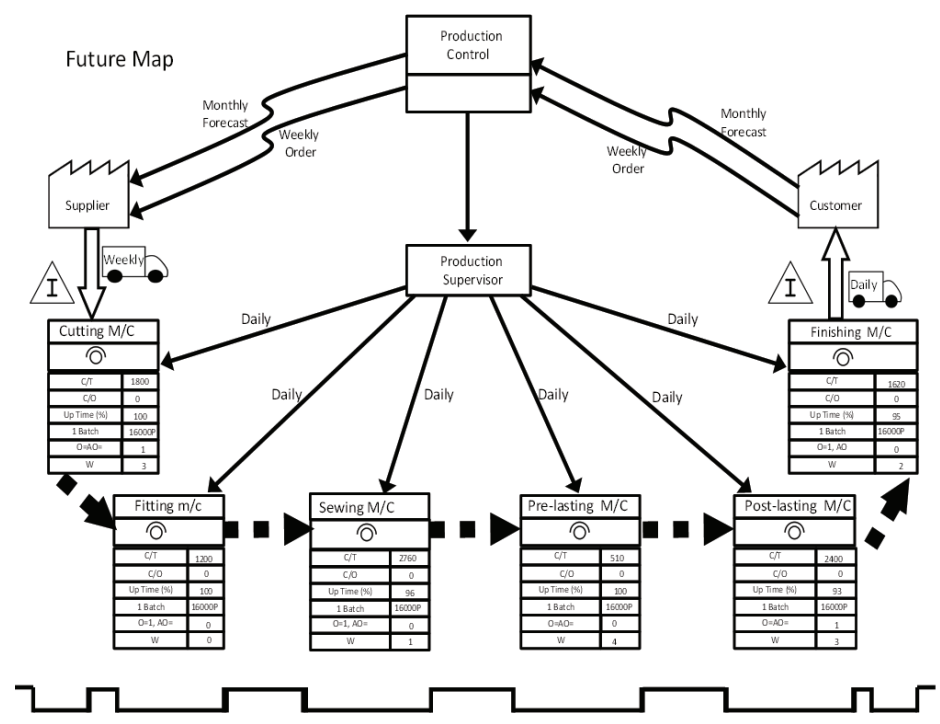

Figure 4. Future VSM of Court Shoe Production Line

\section{Expected Takt Time of Future State}

It is mentioned earlier that takt time is the heartbeat of a production process line. Takt time is the time that needs to produce a single unit of production. The lower it is, the faster the production is. Throughout this study, it was tried to reduce the takt time. At future state, after the adoption of lean tools, the takt time is found
$7.002 \mathrm{sec}$ while at present state production phenomenon it was found $7.20 \mathrm{sec}$.

\section{Achievement of Lean Tools Adoption}

A promising achievement is predicted with the reduced NVD time, lead time and takt time, and improved PCE. An improvement comparison between present and future state is given in the following Figure 5.

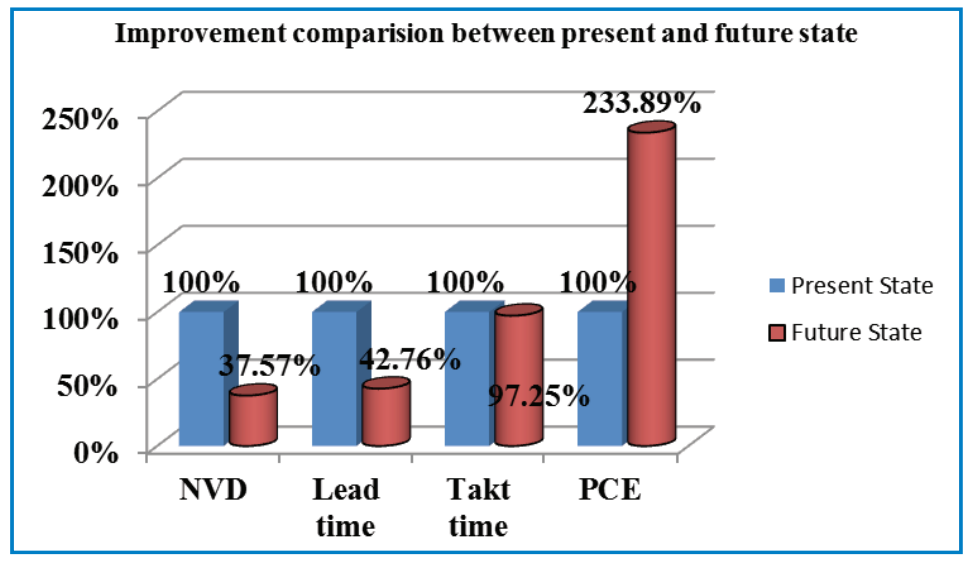

Figure 5. Improvement comparison between present and future state

At future state, it is seen that the NVD time will be reduced by $62.43 \%$, lead time will be reduced by $57.24 \%$, takt time will be reduced by $2.75 \%$ and PCE will be improved by $133.89 \%$. But all of these alluring achievements basically depend on the successful implementation of proposed lean tools. 


\section{TECHNOLOGY ASSESSMENTS}

\section{Assessment of Product Market Technology System Components Sophistication Range and} Innovation Scope of Studied Footwear Industry [33]

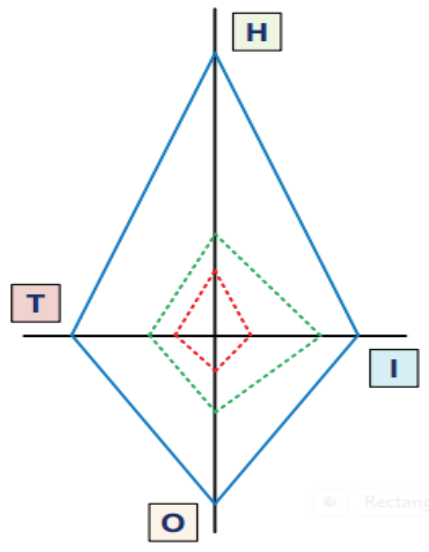

Figure 6. Technology components profile ( $\mathrm{T}$ - technoware, $\mathrm{H}$ - humanware,

I - infoware, O - orgaware). Ideal (Best) profile: Outer shape (blue),

Current profile: Middle shape (green), Minimum profile: Inner shape (red)

Below is the revised scoring table for assessing degree of sophistication of THIOs using a 9-point overlapping scoring scale with 10 for ideal best.

Table 5: Assessment of the degree of sophistication of THIOs

\begin{tabular}{|c|c|c|c|c|c|}
\hline $\begin{array}{c}\text { Technology } \\
\text { Components }\end{array}$ & $\begin{array}{c}\text { LOW Primitive } \\
\text { Score: } 1-2-3\end{array}$ & $\begin{array}{c}\text { MEDIUM } \\
\text { Traditional } \\
\text { Score: } 3-4-5\end{array}$ & $\begin{array}{c}\text { HIGH Modern } \\
\text { Score: } 5-6-7\end{array}$ & $\begin{array}{c}\text { TOP Emerging } \\
\text { Score: 7-8-9 }\end{array}$ & $\begin{array}{c}\text { IDEAL Best } \\
\text { Score: } 10\end{array}$ \\
\hline Technoware & Manual & Powered & Automatic & Programmable & Zero Deviation \\
\hline Humanware & Basic & Superior & Advanced & Extraordinary & Zero Error \\
\hline Infoware & General & Special & Unique & Frontier & Zero unknown \\
\hline Orgaware & Adhoc & Orderly & Managed & Optimized & Zero tolerance \\
\hline
\end{tabular}

Assessment of Product Market Value Using Integrated Business and Technology Strategies of Court Shoe [33]

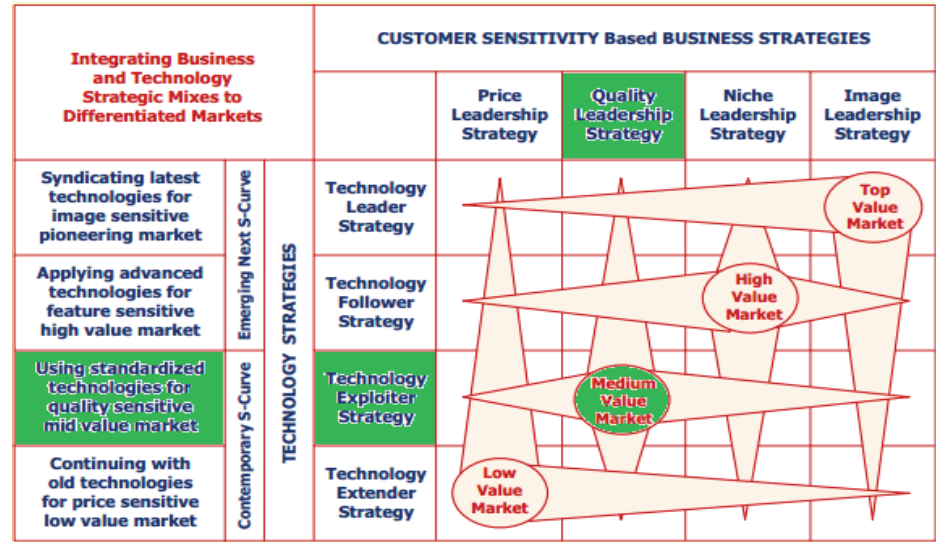

Figure 7. Integrated Business and Technology Strategies 


\section{CONCLUSIONS}

This study provides a case analysis of the improvement of a court shoe production line by reducing the lead time and improving the PCE by using of lean tools. It focuses the renovation of operations by eliminating the NVD time and lead time and improving the PCE through VSM, Pareto Analysis, 5S, and JIT. In a nutshell, it is inferred that a set of lean tools is an effective way to identify and eliminate the manufacturing NVD activities and time.

\section{REFERENCES}

1. Womack, J.P., Jones, D.T., Roos, D., The Machine that Changed the World, HarperCollins Publishers, New York, 1991.

2. Sayid Mia, M.A., Nur-E-Alam, M., Ahmad, F., Kamal Uddin, M., Footwear Industry in Bangladesh: Implementation of Six Sigma Methodology, Ind Eng Manage, 2017, 6, 211, https://doi.org/10.4172/21690316.1000211.

3. Hobbs, D.P., Lean Manufacturing Implementation: A Complete Execution Manual for any Size Manufacturer, J. Ross Publishing, Boca Raton, 2004.

4. Abdullah, F., Rajgopal, J., Lean Manufacturing in the Process Industry. Proceedings of the IIE Research Conference, CD-ROM, 2003, Portland, OR, IIE, Norcross, GA.

5. Ahmad, M., Dhafr, N., Benson, R., Burgess, B., Model for Establishing Theoretical Targets at the Shop Floor Level in Specialty Chemicals Manufacturing Organizations, Robot Comput Integr Manuf, 2005, 21, 4-5, 291-400.

6. Melton, T., The Benefits of Lean Manufacturing: What Lean Thinking Has to Offer the Process Industries, Chem Eng Res Des, 2005, 83, A6, 662-673.

7. Radnor, Z., Changing to a Lean Organisation: The Case of a Chemicals Company, International Journal of Manufacturing Technology and Management, 2000, 1, 4/5, 444-454.
8. Cook, R.C., Rogowski, R.A., Applying JIT Principles to Continuous Process Manufacturing Supply Chains, Production and Inventory Management Journal, 1996, First Quarter, 12-16.

9. Billesbach, J.T., Applying Lean Production Principles to a Process Facility, Production and Inventory Management Journal, 1994, Third Quarter, 40-44.

10.Abdullah, F., Rajgopal, J., Needy, K.L., A Taxonomy of the Process Industry with a View to Lean Manufacturing, Proceedings of the American Society for Engineering Management, Tampa, FL, 2002, 314-321.

11.Abdelmalek, F., Rajgopal, J., Needy, K.L., A Classification Model for the Process Industry to Guide the Implementation of Lean, Engineering Management Journal, 2006, 18, 1, 15-25.

12.Rajenthirakumar, D., Mohanram, P.V., Harikarthik, S.G., Process Cycle Efficiency Improvement Through Lean: A Case Study, International Journal of Lean Thinking, 2011, 2, 1, 46-58.

13.Womack, J.P., Daniel, T.J., Lean Thinking: Banish Waste and Create Wealth in your Corporation, New York, 1996, NY: Simon \& Schuster.

14.Young, H.K., Frank, T.A., Benefits, Obstacles, and Future of Six Sigma Approach, Technovation, 2006, 23, 708-715.

15.Pavlović, K., Božanić, V., Lean and Six Sigma Concepts, International Journal for Quality Research, 2012, 6, 1, 23-28.

16.Carlos, W.M., Optimization in Production Operations, Optimal "Lean Operations" in Manufacturing, (c) 2005-06 Ultramax Corporation, Oct. 5, 2006.

17.Zhen, Y., Food Safety and Lean Six Sigma Model, University of Central Missouri, Oct. 2011.

18. Sayid Mia, M.A., Nur-E-Alam, M., Lutfor Rahman, M., Kamal Uddin, M., Footwear Industry in Bangladesh: Reduction of Lead time by using Lean Tools, Journal of 
Environmental Science, Computer Science and Engineering \& Technology, Sec. C, 2017, 6, 3, 251-259, https://doi.org/10.24214/ jecet.C.6.3.25159.

19. Rother, M., Shook, J., Learning to See: Value Stream Mapping to Add Value and Eliminate MUDA, The Lean Enterprise Institute, Inc., Brookline, MA, 1999.

20.McDonald, T., Van Aken, E.M., Rentes, A.F., Utilizing Simulation to Enhance Value Stream Mapping: A Manufacturing Case Application, International Journal of Logistics: Research and Applications, 2002, 5, 2, 213-232.

21.Frandson, A., Berghede, K., Tommelein, I.D., Takt-Time Planning and the Last Planner, Production Planning and Control; Proceedings IGLC-22, June 2014, Oslo, Norway.

22.Pareto, V., Trattato di Sociologia Generale, Firenze, 1916, Engl.: The Mind and Society, Dover, 1935.

23.Kimber, R.J., Grenier, R.W., Heldt, J.J., Quality Management Handbook, Marcel Dekker, York, NY, 1997.

24.Dyche, J., The CRM Handbook: A Business Guide to Customer Relationship Management, Addison-Wesley, 2001.

25.Arthur, L.J., Rapid Evolutionary Development - Requirements, Prototyping \& Software Creation, John Wiley \& Sons, 1992.

26. Harry, M.J., Six Sigma: A Breakthrough Strategy for Profitability, Quality Progress, 1998, 31, 5, 60-64.
27.Tsuchiya, K., Soon, F., The Practice of Good Housekeeping (5S \& Kaizen), Singapore Productivity and Standards Board, 2008.

28. Monden, Y., Toyota Production System-An Integrated Approach to Just-In-Time, third ed. Engineering \& Management Press, Norcross, Georgia, 1998.

29.Inman, R., Bulfin, R.L., Sequencing of JIT Mixed Model Assembly Lines, Manag Sci, 1991, 37, 901-904.

30.Feld, W.M., Lean Manufacturing: Tools, Techniques, and How To Use Them, The St. Lucie Press, London, 2000.

31.Nahmias, S., Production and Operations Analysis, fourth ed. McGraw Hill, New York, 2001.

32.Tajiri, M., Gotoh, F., TPM Implementation: A Japanese Approach, McGrawHill Inc., New York, 1992.

33.Sharif, N.M., Fundamentals of Technological Innovation for Global Competition, Book of knowledge viewgraphs.

(C) 2017 by the author(s). Published by INCDTP-ICPI, Bucharest, RO. This is an open access article distributed under the terms and conditions of the Creative Commons Attribution license (http://creativecommons.org/licenses/ by/4.0/). 